\title{
Peran Kepala Sekolah dalam Mewujudkan Budaya Kinerja Tinggi Tenaga Pendidik di Sekolah Dasar Muhammadiyah Terpadu Ponorogo
}

\author{
Wahid Hariyanto \\ IAIN Ponorogo, Indonesia \\ Email:Wahidhariyanto7@gmail.com \\ Septy Prasetyaning Tyas \\ MI Singosaren Ponorogo, Indonesia \\ Email: septyprasetyaningtyas@gmail.com
}

DOI: https://doi.org/10.21154/sajiem.v2i2.66

\begin{abstract}
Penelitian ini bertujuan untuk mengungkap praktik peran Kepala Sekolah SDMT Ponorogo dalam mewujudkan budaya kinerja tinggi khususnya padabudaya kinerja tenaga pendidik. Mengingat tenaga pendidik merupakan ujung tombak keberhasilan dalam sebuah pendidikan. Dengan kata lain bermutu tidaknya pendidikan tergantung dari kinerja tenaga pendidiknya. Oleh karena itu, penelitian ini penting dilakukan untuk meningkatkankinerja tenaga pendidik dengan cara merekayasa budaya kerja sehingga menciptakan budaya kinerja tinggi.Hal tersebut dikarenakan berdasarkan penelusuruan belum ada penelitian yang mengupas peran kepala sekolah dalam mewujudkan budaya kinerja tinggi di lembaga pendidikan. Penelitian ini menggunakan pendekatan kualitatif dengan jenis studi kasus. Informan dalam penelitian ini kepala sekolah dan seorangtenaga pendidik. Adapun cara mengumpulkan data dengan metode wawancara dan dokumentasi. Setelah data terkumpul selanjutnya dianalisis dengan konsep dari Miles dan Huberman yang meliputi reduksi data, display data, dan penarikan kesimpulan. Dari hasil analisis menyimpulkan bahwa 1) peran kepala sekolah dalam mewujudkan budaya kinerja tinggi dilakukan dengan sistem
\end{abstract}


collaborative principal rolesyang meliputi peran educator (memberikan pembinaan), motivator (memberikan motivasi kerja), supervisor (mengawasi jalannya kegiatan),leader (memimpin dengan sistem delegasi pada setiap kegiatan), manager (mengelola kegiatan berbasis time schedule). 2) usaha yang dilakukan kepala sekolah dalam menciptakan budaya kinerja tinggi adalah denganpenerapan sistem kerja berbasis full timer dan part timer, penerapan prinsip otoritas dan delegasi, pemantauan kinerja (supervisi), penerapan prinsip keadilan dalam hal insentif, dan penerapan the right man in the right place.

Kata Kunci: Peran Kepala Sekolah; Budaya Kinerja Tinggi

\section{Pendahuluan}

Tenaga pendidik sebagai ujung tombak dalam mencerdaskan generasi muda harus memilikikinerja yang baik. Dikarenakan kinerja tenaga pendidik memiliki korelasi dengan banyak hal yang secara tidak langsung mepengaruhi kredibilitas sebuah lembaga pendidikan. Apalagi dalam era global semacam ini, yang mana lembaga pendidikan dituntut untuk terus meningkatkan kinerja agar memiliki daya saing (competitive advantage). ${ }^{1}$ Diantara kaitan tersebut misalnya saja antara kinerja tenaga pendidik dengan mutu pembelajaran dan prestasi kerja yang diraih. Dalam hal pembelajaran, kinerja seorang tenaga pendidik sangat menentukan prestasi peserta didik. Dan hal ini sesuai dengan hasil riset dari Mohamad Sodik dkk. ${ }^{2}$ Sedangkan yang berkaitan dengan prestasi kerja pendidik, kinerja seorang tenaga pendidik sangat menentukan prestasi kerja yang diraih selama melakukan pengabdian.Kaitan kinerja tenaga pendidik dengan prestasi kerja ini sesuai dengan riset yang dilakukan oleh Harlawan Akhlak Hansyah dkk. ${ }^{3}$

Berkaitan dengan kinerja tenaga pendidik ini, dalam dasa warsa terakhir rendahnya kinerja tenaga pendidik menjadi problem yang disoroti

${ }^{1}$ Mohammad Zaini, "Manajemen Kepemimpinan Profetik: Upaya Meningkatkan Kinerja dan Tanggung Jawab Guru di Lembaga Pendidikan Islam," Southeast Asian Journal of Islamic Education Management 2, no. 1 (2021): 75.

${ }^{2}$ Mohamad Sodik, Yosef Farhan Dafik Sahal, dan N. Hani Herlina, "Pengaruh Kinerja Guru dalam Pelaksanaan Pembelajaran terhadap Prestasi Belajar Siswa pada Mata Pelajaran Alquran-Hadis," Jurnal Penelitian Pendidikan Islam 7, no. 1 (2019): 97.

${ }^{3}$ Harlawan Akhlak Hansyah, Ahmad Firman, dan Sylvia Sjarlis, "Pengaruh Supervisi Akademik, Kompetensi Pedagogik, Dan Kinerja Guru Terhadap Prestasi Kerja Guru Smp Negeri 6 Kalukku Kabupaten Mamuju” 1, no. 2 (2020): 200. 
pemerintah. ${ }^{4}$ Bahkan sampai saat ini rendahnya kinerja tenaga pendidik juga belum sepenuhnya terurai. ${ }^{5}$ Namun demikian, pelan tapi pasti pemerintah mulai mampu mengatasinya. Dan upaya mengatasi ini akan lebih efektif jika terjadi sinergi antara pemerintah dan pengelola lembaga pendidikan dalam hal ini adalah kepala sekolah melalui peran strategis yang dimiliki.Karena secara teoretik kinerja tenaga pendidik di antaranyadipengaruhi oleh kepemimpinan kepala sekolah dalam budaya yang diciptakan. ${ }^{6}$

Kepala sekolah berdasarkan posisinya memiliki beberapa peran strategis. Peran strategis tersebut diantaranya sebagai pengelola lembaga pendidikan dan pemimpin lembaga pendidikan. Kepala sekolah sebagai pengelola lembaga pendidikan identik dengan kegiatan administrasi, sedangkan sebagai pemimpin lembaga pendidikan identik dengan menciptakan iklim kinerja dan budaya kinerja yang efektif untuk mencapai tujuan pendidikan. ${ }^{7}$ Lebih fokus kepada peran kepala sekolah sebagai pemimpin lembaga pendidikan, kepala sekolah bertanggung jawab dalam menetapkan arah dan tujuan lembaga, memberikan bimbingan kepada bawahan serta membangun budaya kinerja yang mendukung pelaksanaan manajemen secara keseluruhan. ${ }^{8}$ Pada poin membangun budaya kinerja inilah kinerja tenaga pendidik bisa lebih ditingkatkan dan dikembangkan menjadi tidak hanya baik akan tetapi kinerja yang tinggi (high performance). Atau dengan kata lain, ketika kepala sekolahmampu mewujudkan budaya kinerja tinggi (high performance culture) di lingkungan lembaga pendidikannya maka mau tidak mau tenaga pendidik juga akan mengikuti alur budaya yang diciptakan sehingga memiliki kinerja yang tinggi (high performance).

Diskusi mengenai peran kepala sekolah sebenarnya sudah banyak dilakukan.Pertama, misalnya saja Nasib Tua Lumban Gaol dan Paningkat Siburian yang mengkaji peran kepala sekolah yang dikaitkan dengan kinerja tenaga pendidik. ${ }^{9}$ Pada penelitian ini telah disebutkan terkait diperlukan budaya yang kondusif akan tetapi belum terdapat pembahasan secara intensif

\footnotetext{
${ }^{4}$ Teguh Firmansyah dan Didi Purwadi, "SBY Kritik Kinerja Guru," News, Republika.co.id (blog), 30 November 2011, https://republika.co.id/berita/lvgmbj/sbykritik-kinerja-guru.

${ }^{5}$ Tim Redaktur, “Kinerja Guru Perlu Diperbaiki,” Kalbar Post.id (blog), Mei 2018, https://kalbarpost.id/kinerja-guru-perlu-diperbaiki/.

${ }^{6}$ Mahmudi, Manajemen Kinerja Sektor Publik (Yogyakarta: UPP AMP YKPN, 2005), 21.

${ }^{7}$ Didin Kurnidin dan Imam Machali, Manajemen Pendidikan: Konsep dan Pengelolaan Pendidikan (Yogyakarta: AR Ruzz Media, 2013), 295.

${ }^{8}$ Burhanuddin, Analisis Administrasi Manajemen dan Kepemimpinan Pendidikan, I (Jakarta: Bumi Aksara, 1994), 61.

${ }^{9}$ Nasib Tua Lumban Gaol dan Paningkat Siburian, "Peran Kepala Sekolah Dalam Meningkatkan Kinerja Guru," Kelola: Jurnal manajemen Pendidikan 5, no. 1 (2018): 66.
} 
terkait budaya kondusif seperti apa yang dimaksud. Kedua, penelitian yang dilakukan oleh Muh. Fitrah yang mengupas tentang peran kepala sekolah dalam meningkatkan mutu pendidikan. ${ }^{10}$ Dalam penelitian ini peran kepala sekolah disinggung secara global sesuai dengan tujuh peran yang melekat pada kepala sekolah serta upaya yang harus dilakukan kepala sekolah dan juga faktor yang mempengaruhi mutu pendidikan. Pada penelitian ini belum ada garis singgung dengan budaya kinerja.Ketiga, penelitian yang dilakukan Muhamad Sholeh yang mengkaji efektivitas peran kepala sekolah dalam meningkatkan kinerja tenaga pendidik." Dalam penelitian ini juga belum ditemukan bagaimana wujud peran kongkrit dari kepala sekolah dalam meningkatkan mutu kinerja tenaga pendidik. Selain penelitian di atas masih terdapat beberapa penelitian lain yang sejenis (meningkatkan kinerja tenaga pendidik), ${ }^{2}$ akan tetapi juga belum ditemukan penelitian yang membahas terkait dengan menciptakan budaya kinerja tinggi (high performance culture) sebagai solusi untuk meningkatkan kinerja pendidik sebagaimana fokus dalam penelitian ini. Sehingga posisi penelitian ini di antara penelitianpenelitian yang telah dilakukan adalah sebagai pelengkap penelitian sebelumnya. Dengan harapan hasil penelitian ini bisa berkontribusi dalam dunia pendidikan khususnya yang terkait dengan penciptaan budaya kinerja tinggi (high performance culture) untuk membangun kinerja tinggi (high performance)di kalangan tenaga pendidik.

Berdasarkan gambaran singkat di atas, maka pembahasan mengenai penciptaan budaya kinerja tinggi (high performance culture) merupakan hal yang menarik untuk ditindaklanjuti. Sebagai upaya menindaklanjuti hal tersebut, Peneliti mengambil lokasi penelitian di Sekolah Dasar Muhammadiyah Terpadu (SDMT) Ponorogo.Untuk menciptakan budaya kinerja tinggi (high performance culture), Kepala Sekolah Dasar Muhammadiyah Terpadu (SDMT) Ponorogo selalu berupaya memaksimalkan peran yang dimiliki. Wujud daribudaya kinerja tinggi (high performance culture)yang diciptakan di antaranya adalah menciptakan iklim kompetisi diantara tenaga pendidik, menerapkan sistem kerja full timer dan part timer, pemberian kebebasan bagi guru untuk mengonsep program kegiatan sekolah,

\footnotetext{
${ }^{10}$ Muh. Fitrah, "Peran Kepala Sekolah dalam Meningkatkan Mutu Pendidikan," Jurnal Penjaminan Mutu 3, no. 1 (2017): 31.

${ }^{11}$ Muhamad Sholeh, "Keefektifan Peran Kepala Sekolah dalam Meningkatkan Kinerja Guru," Jurnal Dinamika Manajemen Pendidikan 1, no. 1 (2016): 41.

${ }^{12}$ Muhammad Faqihudin, "Peran Kepala Sekolah dalam Meningkatkan Kinerja Guru dan Mutu Sekolah," Jurnal Laaroiba 1, no. 1 (2019): 51; Mukhtar, "Strategi Kepala Sekolah dalam Meningkatkan Kinerja Guru pada SMP Negeri di Kecamatan masjid Raya Kabupaten Aceh Besar," Jurnal Magister Administrasi Pendidikan 3, no. 3 (2015): 103.
} 
dan masih banyak lagi kebijakan yang dilakukan untuk menciptakan kinerja tinggi. $^{13}$

\section{Metode Penelitian}

Penelitian ini menggunakan pendekatan kualitatif dengan jenis studi kasusinstrumental. Alasan memilih jenis penelitian ini dikarenakan Peneliti ingin mengungkap tidak hanya pada poin budaya kinerja tinggi (high performance culture), akan tetapi terkait juga dengan bagaimana peran dan usaha kepala sekolah dalam menciptakan budaya kinerja tinggi (high performance culture) diciptakan. Sehingga informan kunci dalam hal ini adalah Kepala Sekolah Dasar Muhammadiyah Terpadu (SDMT) Ponorogo, dan seorang tenaga pendidik sebagai informan pendukung. Penggalian data dari informan tersebut dilakukan dengan wawancara dan dokumentasi. Sedangkan analisis dilakukan sebagaimana konsep dari Miles dan Huberman yang meliputi reduksi, display, dan penarikan kesimpulan. Reduksi dilakukan dengan memilah dan memilih data yang sesuai dengan rumusan masalah. Display dilakukan dengan menarasikan data yang dipilih menjadi paragraf deskripsi dan juga bagan atau gambar yang bisa menjelaskan data yang dimaksud. Sedangkan penarikan kesimpulan dilakukan dengan mengambil poin penting dari setiap rumusan yang dapat memberikan gambaran holistik dari temuan yang ada.

\section{Temuan dan Pembahasan}

\section{Peran Kepala Sekolah Dalam Mewujudkan Budaya Kinerja Tinggi}

Budaya kinerja tinggi merupakan budaya organisasi yang dibangun di atas seperangkat perilaku dan norma yang diterima secara universal yang didorong oleh para pemimpin dan difasilitasi oleh alat dan proses yang optimal. Ini membantu karyawan bekerja seefektif mungkin untuk mencapai tujuan bisnis dan menciptakan nilai. ${ }^{14}$ Budaya kinerja tinggi memiliki beberapa indikator di antaranya komunikasi yang terbuka antara pimpinan dan bawahan, segala sesuatu berfokus kepada pelanggan, memberdayakan karyawan dan pemimpin di setiap tingkat, memiliki proses manajemen yang bagus, dan berinvestasi dalam pertumbuhan karyawan. ${ }^{15}$ Melihat dari pengertian ini maka peran kepala sekolah sangat diperlukan untuk menciptakan budaya kinerja tinggi ini.

\footnotetext{
${ }^{13}$ Imam Saiful Bahri, Wawancara, Ponorogo.

${ }^{14}$ Catherine Daly, "What is a High-Performance Culture, and How Do I Create One?," Thought Exchange (blog), 20 Juli 2021, https://www.thoughtexchange.com/blog/what-is-a-high-performance-culture/.

${ }^{15}$ "5 Characteristics of High Performance Culture," Campbellsville University Online Program (blog), 25 April 2017, https://online.campbellsville.edu/business/highperformance-culture/.
} 
Pada latar belakang di atas telah disinggung bahwa kepala sekolah memiliki dua posisi penting. Posisi penting tersebut ada kaitannya dengan sisi administrasi tata kelola sekolah (manager) dan ada kaitannya dengan penciptaan iklim dan budaya kinerja dalam lingkup satu sekolah (leadership). ${ }^{16}$ Dua peran pokok ini memperlihatkan bahwa kepala sekolah memang harus cakap dalam mengatur seluruh kegiatan rumah tangga sekolahnya. Tidak hanya dari sisi rutinitas yang berkaitan dengan agenda sekolah dan ketatausahaan sekolah, akan tetapi juga dalam sisi menciptakan dan menjaga budaya kerja di kalangan tenaga pendidik tetap kondusif dan produktif.

Menciptakan budaya kerja merupakan pekerjaan penting bagi kepala sekolah. Budaya yang tepat (right culture) dapat mendorong kinerja yang tinggi (high performance). ${ }^{17}$ Kepala sekolah sebagai orang yang memegang kunci dalam perbaikan lembaga, harus mampu menciptakan atmosfer kerja yang mengarah kepadatindakan inovatif, tindakan yang mengkreasi ide-ide baru sebagai basis bagi upaya pengembangan sekolah. ${ }^{18}$ Atau dengan kata lain kepala sekolah harus mampu menyeting budaya sekolah menjadi budaya yang mengarah kepada perbaikan terus-menerus (continuous improvement culture) sehingga output dari budaya tersebut adalah bekerja dengan penuh semangat, efektif, efisien, dan produktif sesuai dengan prosedur kerja yang benar guna mencapai hasil optimal sesuai dengan tanggung jawab yang diberikan. ${ }^{19}$

Upaya untuk mewujudkan kondisi sebagaimana di atas kepala sekolah harus memaksimalkan peran dan fungsinya dalam lembaga pendidikan. Sehingga dengan upaya pemaksimalan peran dan fungsi sumber daya manusia yang ada dapat diberdayakan untuk bekerja dengan kinerja tinggi. Diantara peran kepala sekolah secara umum tercakup dalam istilah emaslim, yaitu (1) educator; (2) manager; (3) administrator; (4) supervisor; (5) leader; (6) innovator; dan (7) motivator. ${ }^{20}$ Sebagai pembanding, dalam perspektif kebijakan pendidikan nasional peran kepala sekolah meliputi (1) educator; (2)

\footnotetext{
${ }^{16}$ Kurnidin dan Machali, Manajemen Pendidikan: Konsep dan Pengelolaan Pendidikan, 295.

${ }^{17}$ Richard L. Daft, The Leadership Experience, Fourth Edition (USA: Thomson Higher Education, 2008), 429.

${ }^{18}$ M. Arifin, Kapita Selekta Pendidikan: Islam dan Umum, III (Bandung: Bumi Aksara, 1995), 155 .

${ }^{19}$ Alfiatun dan Ali Murtadlo, "Manajemen Kinerja Tinggi," https://www.slideshare.net/mobile/visualbeenetwork/manajemen-kinerjatinggidisusun-olehalfiatunali-murtadlodosen-pengampudrs-h-mahfudz-shalahuddinmpd. dan Anwar Prabu Mangkunegara, Manajemen Sumber Daya Manusia Perusahaan (Bandung: Remaja Rosdakarya, 2011), 67.

${ }^{20}$ Jerry H. Makawimbang, Kepemimpinan Pendidikan yang Bermutu (Bandung: Alfabeta, 2012), 61-95. Lihat juga Mulyasa, Menjadi Kepala Sekolah Profesional dalam Konteks Menyukseskan MBS dan KBK (Bandung: Remaja Rosdakarya, 2009), 98.
} 
manager; (3) administrator; (4) supervisor; (5) leader; (6) climate creator; dan (7) entrepreneur. ${ }^{21}$

Proses penciptaan budaya kinerja tinggi tidak cukup hanya dengan satu pelaksanaan peran dari kepala sekolah, akan tetapi perlu collaborative principal rolesdari sekian banyak peran yang dimiliki oleh kepala sekolah. Manakala kepala sekolah memerankan pencipta iklim akan tetapi tidak diiringi dengan peran lain semisal supervisor, maka budaya yang diciptakan tidak akan berjalan maksimal, atau bahkan hanya mampu bertahan beberapa waktu saja. Selain itu, perlu ada pula peran kepala sekolah sebagai manager dan leader untuk mengelola dan memimpin jalannya budaya kinerja tinggi.

Aktualisasi peran kepala sekolah di Sekolah Dasar Muhammadiyah Terpadu (SDMT) Ponorogo dalam mewujudkan budaya kinerja tinggi diantaranya adalah kepala sekolah selalu memotivasi para pendidik untuk selalu membenahi diri dan keluar dari zona nyaman untuk dapat bisa berprestasi. Zona nyaman memang seperti pisau bermata dua. Bagi penganut pro comfort zone, zona nyaman ini bisa memberikan ketenangan dan kenyamanan dalam dalam bekerja. Sedangkan bagi penganut contra comfort zone memandang zona nyaman sebagai faktor penghambat berprestasi dan berpotensi sebagai belenggu kreativitas seseorang. ${ }^{22}$ Melihat kondisi ini dapat diketahui bila Kepala Sekolah Dasar Muhammadiyah Terpadu (SDMT) Ponorogo menganut contra comfort zone. Hal ini ditandai dengan himbauan kepada para tenaga pendidik untuk tidak terlalu menetap di zona nyaman.

Menurut Peneliti, motivasi semacam ini penting dilakukan manakala sebagian besar tenaga pendidiknya penganut pro comfort zone. Dan hal ini jika dikaitkan dengan motivasi X dan Y miliknya Douglas Mc Gregor ${ }^{23}$ maka akan terjadi titik temu. Jika motivasi $\mathrm{X}$ menganggap seseorang termasuk dalam kategori yang kurang bersemangat dalam bekerja, kurang bertanggung jawab dan harus dengan sedikit dipaksa agar mau berprestasi. Maka dalam lingkup pro comfort zone tenaga pendidik merasa tenang dalam bekerja, terlena dengan kenyamanan yang dimiliki sehingga prestasi kerja kurang diperhatikan. Sehingga jika tenaga pendidik dalam posisi ini langkah terbaik yang dapat diambil adalah dengan membuat sistem yang memaksa tenaga pendidik keluar dari zona nyaman sebagaimana yang dilakukan oleh Kepala Sekolah Dasar Muhammadiyah Terpadu (SDMT) Ponorogo.

\footnotetext{
${ }^{21}$ Depdiknas, Standar Kompetensi Kepala Sekolah TK, SD, SMP, SMA, SMK $\mathcal{E} S L B$ (Jakarta: BP. Cipta Karya, 2006).

${ }^{22}$ Retno Utari, “Comfort Zone : Safety Zone atau Danger Zone?,” Desember 2014, https://bppk.kemenkeu.go.id/content/berita/pusdiklat-kekayaan-negara-danperimbangan-keuangan-comfort-zone---safety-zone-atau-danger-zone-2019-11-052fddd6oc/.

${ }^{23}$ Lina Marliani, “Motivasi Kerja dalam Perspektif Douglas Mc Gregor,” Jurnal Unigal, 3, diakses 1 November 2021, https://jurnal.unigal.ac.id > article > download.
} 
Selain memberikan motivasi yang berupa himbauan untukkeluar dari zona nyaman, Kepala Sekolah Dasar Muhammadiyah Terpadu (SDMT) Ponorogo juga memberikan motivasi melalui lantunan hadits yang bertemakan perbaikan kepribadian dan pendidikan. Pemberian motivasi semacam ini menurut Mulyasa termasuk ke dalam motivasi melalui dorongan. ${ }^{24}$ Melalui lantunan hadits Nabi Muhammad Saw. para tenaga pendidik didorong untuk melakukan refleksi diri. Apakah kinerja selama ini sudah sesuai dengan pandangan agama islam atau belum. Jika memang belum, harapannya adalah agar hati tenaga pendidiktergerak untuk melakukan apa yang disabdakan oleh Nabi Muhammad Saw sebagai idola kaum muslim. Dengan demikian kompetensi-kompetensi sebagai tenaga pendidik menjadi semakin kuat. Dan menurut Peneliti, dikarenakan dorongan ini melalui hadits nabi Muhammad Saw, maka termasuk ke dalammotivasi dorongan spiritual.

Selain menggunakan motivasi dalam bentuk himbauan dan dorongan sebagaimana di atas, Kepala Sekolah Dasar Muhammadiyah Terpadu (SDMT) Ponorogo juga memberikan ucapan selamat dan terima kasih bagi pendidik yang telah melaksanakan tugas dengan baik. Berdasarkan informasi dari KepalaSekolah Dasar Muhammadiyah Terpadu (SDMT) Ponorogo dalam mengerjakan tugas yang diampu, tenaga pendidik diberikan kesempatan seluasnya untuk mengekspresikan diri. Misalnya saja dalam hal mengurusi kegiatan sekolah, Kepala Sekolah Dasar Muhammadiyah Terpadu (SDMT) Ponorogo memberikan kesempatan tenaga pendidiknya untuk berkreasi, dan mendesain kegiatan sesuai dengan keinginannya. Meskipun memberikan kelonggaran bagi tenaga pendidik untuk mengekspresikan diri dalam sebuah kegiatan sekolah yang menjadi tanggung jawabnya, Kepala Sekolah Dasar Muhammadiyah Terpadu (SDMT) Ponorogo tetap mengawal jalannya kegiatan agar tujuan kegiatan tercapai. Berdasarkan data di atas, maka Kepala Sekolah Dasar Muhammadiyah Terpadu (SDMT) Ponorogo pada dasarnya melakukan dua hal, yaitu memberikan penghargaan dan kebebasan berkreasi. Sikap memberikan penghargaan ini termasuk dalam sikap memotivasi melalui reward atau penghargaan. ${ }^{25}$ Sedangkan memberi kebebasan berkreasi termasuk ke dalam motivasi aktualisasi diri. ${ }^{26}$ Motivasi melalui reward atau penghargaan dan kebebasan berkreasi ini termasuk dalam motivasi tataran yang tinggi. Karena dalam teori segitigamotivasi hierarki kebutuhan AbrahamMaslowsecara berurutan menempati posisi pertama dan kedua dari atas yaitu aktualisasi diri dan penghargaan. Pemberian motivasi kepada tenaga pendidik sebagaimana dijelaskan di atas menurut Peneliti masuk

\footnotetext{
${ }^{24}$ Mulyasa, Menjadi Kepala Sekolah Profesional: Dalam Konteks Menyukseskan MBS dan KBK (Bandung: Remaja Rosdakarya, 2003), 120.

${ }^{25}$ Mulyasa, 120.

${ }^{26}$ Khoirul Muslimin, "Implementasi Teori Hierarki Abraham Maslow dalam Meningkatkan Kinerja Dosen UNISNU Jepara,” Jurnal An-Nida 8, no. 1 (Juni 2016): 115.
} 
dalam kategori karakteristik budaya kinerja tinggi poin komunikasi yang terbuka.

Selain memaksimalkan peran sebagai motivator, Kepala Sekolah Dasar Muhammadiyah Terpadu (SDMT) Ponorogo juga memaksimalkan perannya sebagai supervisor. Untuk mewujudkan budaya kinerja tinggi,Kepala Sekolah Dasar Muhammadiyah Terpadu (SDMT) Ponorogo selalu melakukan supervisi terkait kegiatan atau program yang dilaksanakan. Sebagai seorang supervisor, Kepala Sekolah Dasar Muhammadiyah Terpadu (SDMT) Ponorogo menjalankan tugas pengawasan, pengendalian, pembinaan, pengarahan, dan pemberian contoh kepada tenaga pendidik yang ada di sekolahnya. Pada posisi sebagai supervisor, karena Kepala Sekolah Dasar Muhammadiyah Terpadu (SDMT) Ponorogo melakukan pembinaan dan pengarahan pada hakikatnya juga melakukan peran sebagai educator. Karena kepala sekolah sebagai educator bertugas memberikan dorongan, bimbingan dan memberikan contoh kepada tenaga pendidik agar bisa menjalankan tugas secara maksimal. ${ }^{27}$ Selanjutnya, diantara hal penting kepala sekolah sebagai supervisor adalah memahami tugas dan sistem kerja tenaga pendidiknya. Sehingga dalam melaksanakan tugasnya seorang supervisor tidak hanya mengawasi jalannya kegiatan tetapi juga memberikan pembinaan apabila terjadi hal yang kurang sesuai dengan prosedur yang ada. Maka dari itu praktis kepala sekolah harus memiliki pengetahuan dan pemahaman terkait tugas yang dilakukan oleh bawahannya. ${ }^{28}$

Diantara supervisi yang dilakukan oleh Kepala Sekolah Dasar Muhammadiyah Terpadu (SDMT) Ponorogo adalah supervisi kegiatan intrakurikuler maupun ekstrakurikuler. Supervisi kegiatan intrakurikuler (pembelajaran) diantaranya dilakukan dengan mengunjungi kelas-kelas dan mengecek pendidik yang belum datang di kelasnya. Sedangkan supervisi ekstrakurikuler dilakukan dengan mengawasi jalannya kegiatan atau program yang sedang dilakukan. Menurut Burhanudin, kunjungan kelas merupakan supervisi yang bertujuan untuk membantu tenaga pendidik jika mengalami permasalahan-permasalahan seputar proses pembelajaran. Melalui kunjungan kelas ini tenaga pendidik didorong untuk menemukan solusi atas permasalahan yang dihadapi dengan menganalisis secara kritis masalah yang mereka hadapi. ${ }^{29}$ Dalam hal ini berlaku juga untuk supervisi kegiatan ekstrakurikuler.Karena pada dasarnya pengawasan intrakurikuler dan ekstrakurikuler ini memiliki poin yang sama, yaitu melakukan pengawasan

\footnotetext{
${ }^{27}$ Erus Rusdiana, "Peran Kepemimpinan Kepala Sekolah Sebagai Educator dalam Meningkatkan Kompetensi Guru," Indonesian Journal of Education management $\mathcal{E}$ Administration Review 2, no. 1 (Juni 2018): 235.

${ }^{28}$ Herabudin, Adminisrasi dan Supervisi Pendidikan (Bandung: Pustaka Setia, 2009), 210.

${ }^{29}$ Burhanuddin, Analisis Administrasi Manajemen dan Kepemimpinan Pendidikan (Jakarta: Bumi Aksara, 1994), 328.
} 
ketika kegiatan sedang berlangsung, sehingga apabila terjadi masalah dalam pelaksanaannya maka bisa segera dicarikan solusinya.Dan sebagai tindak lanjut atas masalah yang dihadapi, Kepala Sekolah Dasar Muhammadiyah Terpadu (SDMT) Ponorogo melaksanakan rapat evaluasi dan koordinasi.Proses supervisi merupakan bagian dari sistem manajemen pada aspek check, sehingga menurut Peneliti peran supervisor ini mendukung penciptaan budaya kinerja tinggi pada karakteristik proses manajemen yang bagus.

Dalam melaksanakan kegiatan, Kepala Sekolah Dasar Muhammadiyah Terpadu (SDMT) Ponorogo membagi wewenang kepada tenaga pendidiknya. Sehingga di Sekolah Dasar Muhammadiyah Terpadu (SDMT) Ponorogo berlaku sistem pelaksanaan program kegiatan berdasarkan pembagian tugas, tanggung jawab, dan penjadwalan(doing program by delegation, responsibility, and time schedule). Secara teori pelaksanaan pendelegasian dan tanggung jawab tugas ini termasuk ke dalam gaya kepemimpinan delegatif (peran leader). ${ }^{30}$ Sedangkan pengelolaan program kegiatan dan sumber daya manusia berbasis time schedulesebagaimana di atas merupakan bagian dari peran kepala sekolah sebagai manager..$^{31}$ Jika kesemua hal tersebut dikaitkan dengan karakteristik dari budaya kinerja tinggi, maka peran kepala sekolah Dasar Muhammadiyah Terpadu (SDMT) Ponorogo mendukung karakteristik memberdayakan karyawan.

Dari uraian analisis di atas, dalam mewujudkan budaya kinerja tinggi, Kepala Sekolah Dasar Muhammadiyah Terpadu (SDMT) Ponorogo memaksimalkan peran yang dimiliki seperti motivator, supervisor, leader, dan managersebagai pilar penyangga karakter budaya kinerja tinggi. Jika disandingkan antara peran sebagai pilar dan karakteristik budaya kinerja tinggi sebagai Dan jika peran ini dikaitkan dengan karakteristik terciptanya budaya kinerja tinggi dapat digambarkan sebagai berikut:

${ }^{30}$ Malayu S. P. Hasibuan, Manajemen Sumber Daya Manusia (Jakarta: Bumi Aksara, 2009), 172.

${ }^{31}$ Fauzi Sayuti, "Peran Kepala Sekolah dalam Meningkatkan Mutu Pendidikan Islam," n.d., https://media.neliti.com/media/publications/264583-peran-kepalasekolah-dalam-peningkatan-m-o2f6f6fb.pdf. 


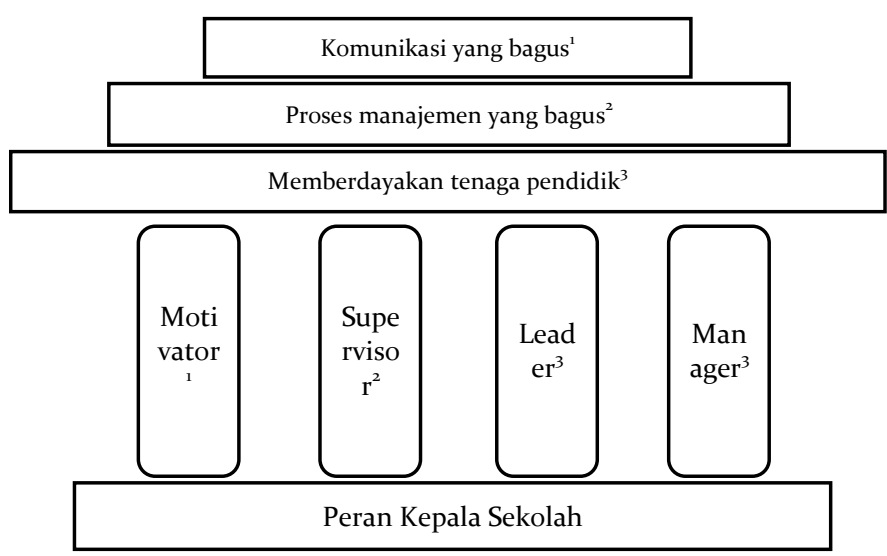

Gambar 1. Peran Kepala Sekolah sebagai Penyangga Karakteristik Budaya Kinerja Tinggi di Sekolah Dasar Muhammadiyah Terpadu (SDMT) Ponorogo

\section{Strategi Kepala Sekolah Dalam Mewujudkan Budaya Kinerja Tinggi}

Adalah Peran dan strategi, dua hal yang tidak dapat dipisahkan. Keduanya berjalan beriringan sebagai perangkat mencapai tujuan. Peran yang dilakukan oleh kepala sekolah sebagaimana di atas perlu didukung strategi yang efektif agar budaya kinerja tinggi semakin mengakar kuat. Di antara strategi yang digunakan oleh Kepala Sekolah Dasar Muhammadiyah Terpadu (SDMT)Ponorogo adalah dengan menerapkan sistem kerja full timer dan part timer. Sehingga terdapat tenaga pendidik full timer dan tenaga pendidik part timer. Tenaga pendidik full timer adalah tenaga pendidik yang dalam satu pekan masuk penuh. Sedangkan tenaga pendidik part timer adalah tenaga pendidik yang hanya masuk pada jam kerjanya saja, yakni pada saat jam mengajar di sekolah.Dalam hal ini kepala sekolah memberlakukan sistem pembagian tenaga pendidik berdasarkan jumlah waktu bekerja (working time). Pembagian semacam ini jika dikelola dengan baik bisa memacu budaya kompetisi yang baik di antara para tenaga pendidik. Sebaliknya, jika tidak dikelola dengan baik juga bisa menimbulkan risiko terciptanya kubu full timer dan kubu part timer yang rentan adanya konflik..$^{32} A$ pabila hal ini sampai terjadi maka yang harus dilakukan oleh kepala sekolah harus mengadakan komunikasi yang baik diantara kelompok yang bersangkutan. ${ }^{33}$ Pengaturan sistem kerja, suasana kerja, termasuk kedisiplinan dan lingkungan fisik semacam ini termasuk pada penciptaan iklim kerja,yakni salah satunya

${ }^{32}$ J. Winardi, Manajemen Perilaku Organisasi, III (Jakarta: Kencana, 2009), 409.

${ }^{33}$ Winardi, 451. 
menciptakan dan mengelola iklim suasana berkompetisi agar setiap tenaga sumber daya manusia termotivasi untuk bersaing. ${ }^{34}$

Selain penerapan sistem tersebut, Kepala Sekolah Dasar Muhammadiyah Terpadu (SDMT)Ponorogojuga memberikan kebebasan kepada tenaga pendidik untuk berekspresi dalam memajukan sekolah. Tenaga pendidikdiberikan kebebasan dan otoritas untuk membuat program kegiatan dalam satu tahun pelajaran. Program kegiatan dalam satu tahun pelajaran tersebut kemudian dikomunikasikan dengan kepala sekolah, yang apabila disetujui maka tenaga pendidik tersebut didelegasikan sebagai ketua pelaksananya. Dalam hal ini kepala sekolah telah memberikan semacam otoritas dan pendelegasian bagi guru untuk melakukan suatu kegiatan kerja sesuai dengan kontribusinya. ${ }^{35}$

Strategi lain yang dilakukan Kepala Sekolah Dasar Muhammadiyah Terpadu (SDMT)Ponorogountuk menciptakan budaya kinerja tinggi adalah dengan penerapan sistem supervisi pada setiap kesempatan. Pada proses supervisi, Kepala Sekolah Dasar Muhammadiyah Terpadu (SDMT)Ponorogoselalu memantau kinerja tenaga pendidiknya, baik di dalam maupun di luar kelas. Apabila kedapatan tenaga pendidik bekerja dengan tidak sesuai dengan standar kerja yang ditetapkan atau tidak disiplin maka tenaga pendidik tersebut akan ditegur secara halus sebagai tanda peringatan. ${ }^{36}$

Melihat dua kondisi sebagaimana di atas yaitu kebebasan beraktualisasi dan adanya supervisi, menandakan Kepala Sekolah Dasar Muhammadiyah Terpadu(SDMT) Ponorogomenerapkan sistem yang seimbang. Dalam artian, di satu sisi memberikan kesempatan seluasnya kepada tenaga pendidik untuk mengekspresikan diri melalui program kegiatan, di sisi yang lain Kepala Sekolah Dasar MuhammadiyahTerpadu (SDMT)Ponorogo juga melakukan sistem kontrol melalui supervisi yang dilakukan.

Selain menggunakan langkah strategi sebagaimana di atas, Kepala Sekolah Dasar Muhammadiyah Terpadu (SDMT)Ponorogojuga menerapkan prinsip keadilan. Prinsip keadilan ini diwujudkan Kepala Sekolah Dasar Muhammadiyah Terpadu (SDMT)Ponorogodengan memberikan insentif yang tepat bagi para tenaga pendidik berdasarkan pembagian sistem dan beban kerja. ${ }^{37}$ Selain prinsip keadilan, Kepala Sekolah Dasar Muhammadiyah (SDMT) Terpadu Ponorogojuga menerapkan prinsip the right man in the right place dalam menempatkan posisi tenaga pendidiknya. Dan terwujudnya sistem

\footnotetext{
${ }^{34}$ Enco Mulyasa, Menjadi Kepala Sekolah Profesional (Bandung: Rosdakarya, 2007), 120-121.

${ }^{35}$ Suryadi Prawirosentono, Kebijakan Kinerja Karyawan (Yogyakarta: BPFE, 1999), 27.

${ }^{36}$ Wibowo, Budaya Organisasi: Sebuah Kebutuhan untuk Meningkatkan Kinerja Jangka Panjang, III (Jakarta: RajaGrafindo Persada, 2013), 386.

37382.
} 
kinerja tinggi tersebut tidak terlepas dari usaha awal Kepala Sekolah Dasar Muhammadiyah (SDMT) Terpadu Ponorogodalam mencari orang yang tepat yang akan bergabung di lembaga pendidikanya. ${ }^{38}$

Berdasarkan hasil analisis di atas, maka dapat disimpulkan bahwa strategi yang dilakukan Kepala Sekolah Dasar Muhammadiyah Terpadu (SDMT)Ponorogo untuk mewujudkan budaya kinerja tinggi (high performance culture) melalui penerapan sistem kerja berbasis full timer dan part timer, penerapan prinsip otoritas dan delegasi, pemantauan kinerja (supervisi), penerapan prinsip keadilan dalam hal insentif, dan penerapan the right man in the right place.Secara lebih jelas dapat dilihat pada gambar di bawah ini.

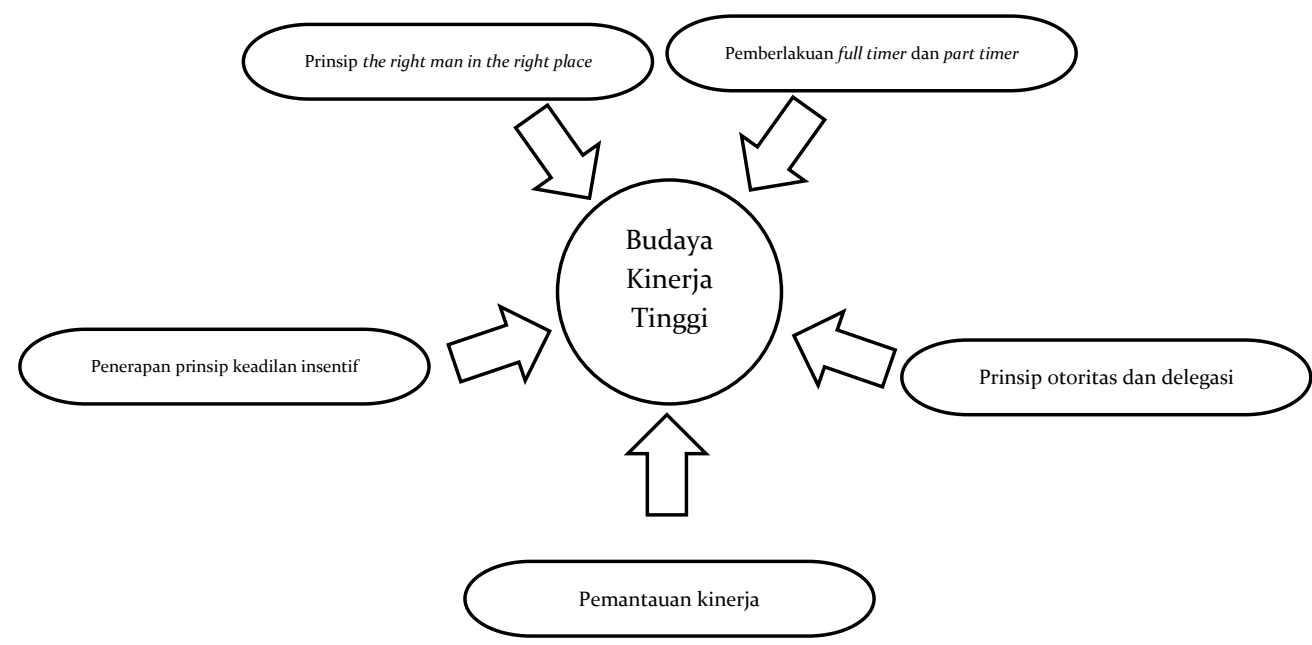

Gambar 2. Strategi Kepala Sekolah dalam Mewujudkan Budaya Kinerja Tinggi di Sekolah Dasar Muhammadiyah Terpadu (SDMT) Ponorogo

\section{Kesimpulan}

Budaya kinerja tinggi (high performance culture) sangat diperlukan oleh sebuah lembaga pendidikan untuk meningkatkan mutu kinerja tenaga pendidik. Untuk mewujudkan budaya kinerja tinggi tersebut dibutuhkan aksi kolaboratif (collaborative action) antara peran kepala sekolah dan strategi pembentuk budaya kinerja tinggi dari kepala sekolah. Dikarenakan antara peran kepala sekolah dan strategi kepala sekolah bagaikan dua sisi mata uang yang saling melengkapi. Peran kepala sekolah yang dibutuhkan untuk mewujudkan budaya kinerja tinggi (high performance culture) diantaranya peran sebagaieducator, motivator, supervisor,leader, dan manager. Sedangkan

${ }^{38} 379$. 
strategi yang bisa diaplikasikan untuk mewujudkan budaya kinerja tinggi (high performance culture) adalah dengan menerapkan sistem kerja berbasis full timer dan part timerpada tenaga pendidik, menerapkan prinsip otoritas dan delegasi dalam membuat dan mengeksekusi program kegiatan, memantau kinerja (supervisi) tenaga pendidik dalam melaksanakan tugas, menerapkan prinsip keadilan yang disesuaikan dengan beban tugas dan tanggung jawab manakala memberikan insentif, dan menerapkan prinsip the right man in the right placemanakala menempatkan tenaga pendidik pada posisi tertentu.

\section{Daftar Pustaka}

Campbellsville University Online Program. "5 Characteristics of High Performance Culture," 25 April 2017. https://online.campbellsville.edu/business/high-performanceculture/.

Alfiatun, dan Ali Murtadlo. "Manajemen Kinerja Tinggi." PowerPoint, n.d. https://www.slideshare.net/mobile/visualbeenetwork/manajemenkinerja-tinggidisusun-olehalfiatunali-murtadlodosen-pengampudrs-hmahfudz-shalahuddin-mpd.

Arifin, M. Kapita Selekta Pendidikan: Islam dan Umum. III. Bandung: Bumi Aksara, 1995.

Burhanuddin. Analisis Administrasi Manajemen dan Kepemimpinan Pendidikan. I. Jakarta: Bumi Aksara, 1994.

-_- Analisis Administrasi Manajemen dan Kepemimpinan Pendidikan. Jakarta: Bumi Aksara, 1994.

Daft, Richard L. The Leadership Experience. Fourth Edition. USA: Thomson Higher Education, 2008.

Daly, Catherine. "What is a High-Performance Culture, and How Do I Create One?" Thought Exchange (blog), 20 Juli 2021. https://www.thoughtexchange.com/blog/what-is-a-high-performanceculture/. 
Depdiknas. Standar Kompetensi Kepala Sekolah TK, SD, SMP, SMA, SMK $\mathcal{E}$ SLB. Jakarta: BP. Cipta Karya, 2006.

Faqihudin, Muhammad. "Peran Kepala Sekolah dalam Meningkatkan Kinerja Guru dan Mutu Sekolah.” Jurnal Laaroiba 1, no. 1 (2019): 51-63.

Firmansyah, Teguh, dan Didi Purwadi. "SBY Kritik Kinerja Guru." News. Republika.co.id (blog), $30 \quad$ November 2011. https://republika.co.id/berita/lvgmbj/sby-kritik-kinerja-guru.

Fitrah, Muh. "Peran Kepala Sekolah dalam Meningkatkan Mutu Pendidikan." Jurnal Penjaminan Mutu 3, no. 1 (2017): 31-42.

Gaol, Nasib Tua Lumban, dan Paningkat Siburian. "Peran Kepala Sekolah Dalam Meningkatkan Kinerja Guru.” Kelola: Jurnal manajemen Pendidikan 5, no. 1 (2018): 66-73.

Hansyah, Harlawan Akhlak, Ahmad Firman, dan Sylvia Sjarlis. "Pengaruh Supervisi Akademik, Kompetensi Pedagogik, Dan Kinerja Guru Terhadap Prestasi Kerja Guru Smp Negeri 6 Kalukku Kabupaten Mamuju" 1, no. 2 (2020): 200-208.

Hasibuan, Malayu S. P. Manajemen Sumber Daya Manusia. Jakarta: Bumi Aksara, 2009.

Herabudin. Adminisrasi dan Supervisi Pendidikan. Bandung: Pustaka Setia, 2009 .

Kurnidin, Didin, dan Imam Machali. Manajemen Pendidikan: Konsep dan Pengelolaan Pendidikan. Yogyakarta: AR Ruzz Media, 2013.

Mahmudi. Manajemen Kinerja Sektor Publik. Yogyakarta: UPP AMP YKPN, 2005.

Makawimbang, Jerry H. Kepemimpinan Pendidikan yang Bermutu. Bandung: Alfabeta, 2012.

Mangkunegara, Anwar Prabu. Manajemen Sumber Daya Manusia Perusahaan. Bandung: Remaja Rosdakarya, 2011. 
Marliani, Lina. "Motivasi Kerja dalam Perspektif Douglas Mc Gregor." Jurnal Unigal. Diakses 1 November 2021. https://jurnal.unigal.ac.id > article > download.

Mukhtar. "Strategi Kepala Sekolah dalam Meningkatkan Kinerja Guru pada SMP Negeri di Kecamatan masjid Raya Kabupaten Aceh Besar." Jurnal Magister Administrasi Pendidikan 3, no. 3 (2015): 103-17.

Mulyasa. Menjadi Kepala Sekolah Profesional: Dalam Konteks Menyukseskan MBS dan KBK. Bandung: Remaja Rosdakarya, 2003.

Mulyasa, Enco. Menjadi Kepala Sekolah Profesional. Bandung: Rosdakarya, 2007.

Muslimin, Khoirul. "Implementasi Teori Hierarki Abraham Maslow dalam Meningkatkan Kinerja Dosen UNISNU Jepara." Jurnal An-Nida 8, no. 1 (Juni 2016): 115-21.

Prawirosentono, Suryadi. Kebijakan Kinerja Karyawan. Yogyakarta: BPFE, 1999.

Rusdiana, Erus. "Peran Kepemimpinan Kepala Sekolah Sebagai Educator dalam Meningkatkan Kompetensi Guru." Indonesian Journal of Education management $\mathcal{E}$ Administration Review 2, no. 1 (Juni 2018): 231-36.

Sholeh, Muhamad. "Keefektifan Peran Kepala Sekolah dalam Meningkatkan Kinerja Guru." Jurnal Dinamika Manajemen Pendidikan 1, no. 1 (2016): 41-54.

Sodik, Mohamad, Yosef Farhan Dafik Sahal, dan N. Hani Herlina. "Pengaruh Kinerja Guru dalam Pelaksanaan Pembelajaran terhadap Prestasi Belajar Siswa pada Mata Pelajaran Alquran-Hadis.” Jurnal Penelitian Pendidikan Islam 7, no. 1 (2019): 97-112.

Tim Redaktur. “Kinerja Guru Perlu Diperbaiki.” Kalbar Post.id (blog), Mei 2018. https://kalbarpost.id/kinerja-guru-perlu-diperbaiki/.

Utari, Retno. "Comfort Zone: Safety Zone atau Danger Zone?," Desember 2014. https://bppk.kemenkeu.go.id/content/berita/pusdiklatkekayaan-negara-dan-perimbangan-keuangan-comfort-zone---safetyzone-atau-danger-zone-2019-11-05-2fddd6oc/. 
Wibowo. Budaya Organisasi: Sebuah Kebutuhan untuk Meningkatkan Kinerja Jangka Panjang. III. Jakarta: RajaGrafindo Persada, 2013.

Winardi, J. Manajemen Perilaku Organisasi. III. Jakarta: Kencana, 2009.

Zaini, Mohammad. "Manajemen Kepemimpinan Profetik: Upaya Meningkatkan Kinerja dan Tanggung Jawab Guru di Lembaga Pendidikan Islam." Southeast Asian Journal of Islamic Education Management 2, no. 1 (2021): 74-85. 
SOUTHEAST ASIAN JOURNAL OF ISLAMIC EDUCATION MANAGEMENT 2 (2) 2021 